\title{
Феномен святости в системе религиозно-философских воззрений
}

\author{
Zoja Kuca \\ Uniwersytet Marii Curie-Skłodowskiej w Lublinie \\ zoe@umcs.pl
}

\begin{abstract}
Zoja Kuca, Phenomenon of Sanctity in the System of Religious and Philosophical Views, Elpis, 16 2014: 61-73.
Zoja Kuca, Fenomen świętości w systemie poglądów filozoficzno-religijnych, Elpis, 16 2014: 61-73.

Abstract: The analysis of the phenomenon of sanctity from the religious, philosophical, theological and Orthodox perspective is conducted by means of a semantic, etymological and structural examination of this concept. One of the work's objectives is to highlight the different conceptual meanings of sanctity called for by the use of a comparative method. The point of departure was the biblical understanding of sanctity which substantially approaches the idea as the quality of deity, later developed in the Patristic teachings and supplemented by religion experts and philosophers. Based on that, the concept of sanctity is viewed in four semantic levels: 1) sanctity as sanctity, i.e. a quality typical of God and His chosen ones; its achievement is possible through the process of theosis [deification]; 2) sanctity as numinosum, or a particular dimension of transcendence leading to a unique experience in the human psyche; 3 ) sanctity as sacrum, or a higher level of being, ontological reality, the original reality manifested in hierophanies; and finally 4) sanctity as perfection, moral virtue achieved by a person through personal development.
\end{abstract}

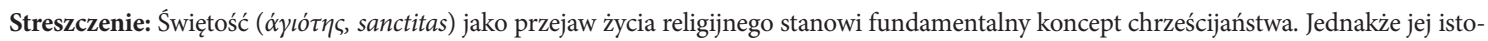
towe rozpoznanie i uzmysłowienie możliwe jest na drodze zsyntetyzowania ujęć różnych nurtów i dyscyplin religioznawczych, fenomenologicznych, filozoficznych, socjologicznych i językowych.

Teologia mistyczna Kościoła prawosławnego zgłębia sens świętości na podstawie Pisma Świętego, dzieł Ojców Kościoła i mistyków, pojmując go jako współudział człowieka w naturze boskiej, osiągnięcie przez człowieka stanu przebóstwienia (theosisu), czyli przemiany całego jego jestestwa przez łaskę Boga w sakramencie eucharystii. Święty Antoni wyznaczył ostateczny cel chrześcijanina jako „życie w Bogu” i określił to „szczytem doskonałości”. W tym traktowaniu świętości szczególną rolę odgrywa teologia apofatyczna i jej warsztat terminologiczny.

Fenomenologiczne pojmowanie świętości odstępuje od tradycyjnego, teologicznego traktowania i skupia uwagę przede wszystkim na opisie wewnętrznych przeżyć psychologicznych podczas kontaktu z bóstwem. Za twórcę tego podejścia uważa się Rudolfa Otto, używającego pojęcia numinosum zamiast terminu „świętość”. Niemiecki fenomenolog wyodrębnia kluczowe formy przeżywania sacrum w doświadczeniu religijnym. W jego ujęciu doznania psychiki ludzkiej w kontakcie z numinosum są następujące: a) uczucie zależności stworzenia; b) mysterium tremendum - uczucie mistycznego przerażenia, składające się z czterech elementów (zgrozy, majestatu, mocy i tajemnicy); c) mysterium fascinans - uczucie zachwytu i fascynacji. Poglądem charakterystycznym dla filozofa jest przekonanie o racjonalnej i irracjonalnej obecności świętości, której najwyższym przejawem jest Chrystus. Otto definiuje nie tylko procesy zachodzące w psychice homo religiosus, ale również mechanizmy „przyciągania” jej do świętości. Mircea Eliade kontynuuje rozważania Otto, skupiając się nie tyle na świecie wewnętrznym osoby religijnej, ile na zewnętrznych przejawach sacrum w postaci zmysłowo dostępnych objawień - hierofanii. Źródłem hierofanii w filozofii religii Eliadego jest bezosobowa postać Absolutu, podczas gdy sacrum staje się absolutną, ontologicznie pierwotną rzeczywistością, pełnią bytu, przyczyną wszelkiego istnienia.

Amerykański religioznawca William James określa stan świętości człowieka jako boskie opanowanie i odrodzenie duszy, przejawiające się w określonym stanie psychicznym. Wyodrębnia on cztery główne właściwości stanu duszy osoby świętej: ascetyzm, siłę wewnętrzną, czystość i miłosierdzie.

Rosyjski filozof religii, Mikołaj Bierdiajew, traktuje świętość w kategoriach daru Bożego i powołania - gdy człowiek je realizuje, zbliża się ku wolności i pełni swojej osobowości. Uczony wprowadza nowe pojęcie w tym kontekście - świętości pojmowanej jako ofiara na drodze twórczości, na drodze ku genialności.

Współczesna filozofia religii, której wybitnym przedstawicielem badającym fenomen świętości jest Lui Dupré, rozpatruje sacrum jako kategorię subiektywną, opisując ją w opozycji do kategorii profanum. Takie podejście, mimo znacznego uproszczenia i zawężenia, również uwzględnia obecność ontologicznej rzeczywistości, która - wedle Duprégo - dąży do wchłonięcia względnej rzeczywistości profanicznej. Dzięki temu sacrum odgrywa konstruktywną i konsolidacyjną rolę w społeczeństwie.

Podejście socjologiczno-etyczne skupia uwagę na moralnym i duchowym doskonaleniu się człowieka oraz na tych namacalnych efektach jego świętości, które w sposób istotny wpłynęly na otoczenie. Podejście to charakterystyczne jest dla Starego Testamentu oraz większości słowników encyklopedycznych, traktujących o świętości jako właściwości konkretnej osobowości. Właśnie starobiblijne pojmowanie świętości utożsamiane jest z doskonałością moralną. Święty człowiek zawsze był obdarzony wysokim poziomem moralności, czystości duszy i ciała. Natomiast semantyka rdzenia свяm sięga korzeni prasłowiańskich i posiada głęboki przedchrześcijański sens sakralny.

W ten sposób fenomen świętości jako zjawisko można rozpatrywać na czterech płaszczyznach semantycznych: 1) świętość jako świętość, tzn. właściwość cechująca Boga i Jego wybrańców, której osiągnięcie jest dla nich możliwe w procesie theosisu (ubóstwienia); 2) świętość jako numinosum, czyli szczególny wymiar transcendencji, wywołujący w psychice ludzkiej określone przeżycia; 3) świętość jako sacrum, czyli wyższa sfera bytu, ontologiczna rzeczywistość, pierwotne realia objawiające się w hierofaniach; 4) świętość jako doskonałość, cnota moralna osiągana przez człowieka w trakcie osobistego rozwoju.

Keywords: Christianity, holiness, holy, orthodox, asceticism, sacred, profane

Słowa kluczowe: Cerkiew, świętość, święty, chrześcijaństwo, ascetyzm, sacrum, profanum

Ключевые слова: Церковь, святость, святой, Православие, аскетизм, сакральный, профанный

Феномен святости как таковой первоначально выступает в иудео-христианской письменности на страницах Библии. Священное писание содержит свыше восьмисот устойчивых фраз с корнем свят, в то время как слово святость употреблено 23 раза. В Ветхом Завете идея святости проявляется в контексте боже- 
ственного свойства: «Кто, как Ты, Господи, между богами? Кто, как Ты, величествен святостью, досточтим хвалами, Творец чудес?» (Исх 15:11)훌 исключительного свойства человека: «а вы будете у Меня царством священников и народом святым» (Исх 19:6); а также свойства предметов, вступивших в непосредственную связь с божественным началом: «И сказал Бог: не подходи сюда; сними обувь твою с ног твоих, ибо место, на котором ты стоишь, есть земля святая» (Исх 3:5). Уже вторая глава Бытия дает предпосылку к феномену святости в глаголе освящать: «И благословил Бог седьмой день, и освятил его, ибо в оный почил от всех дел Своих, которые Бог творил и созидал» (Быт 2:3). По мере углубления в чтение Библии можно встретить новые речевые обороты, вытекающие из семантического определения святости: святыня, святилище, Святая Святых, посвятить, святейший, святиться, святить (Исх 15:13, 15:17, 26:33, 32:29, Чис 18:10, Мф 6:9, 1Петр 3:15). Важно отметить, что Священное Писание не только упоминает о святости, но и частично раскрывает смысл данного выражения, в особенности Новый Завет. Тем не менее, уже в Ветхом Завете Господь призывает человека к святости как к отличительной черте своей божественной природы: «Я - Господь Бог ваш: освящайтесь и будьте святы, ибо Я свят» (Лев 11:44).

На древнееврейском языке слово святость (кадо́ш - שוּר) означало, в первую очередь, нечто таинственное, иноприродное миру, отделенное, требующее соблюдения благоговейной дистанции. Святость являлась преимущественно свойством трансцендентного Божества и не могла быть описана в катафатических терминах ${ }^{2}$. В Ветхом Завете все, что посвящалось Богу, именовалось „святым”, т.е. считалось отделенным, обособленным: «Если же то будет скот, который приносят в жертву Господу, то все, что дано Господу, должно быть свято» (Лев 27:9). Сила и проявление библейского понятия святости заключалось в двойственности состояния отделения и соединения: Израиль постигал Бога как Владыку мира как раз в Его отдаленности от мира, и в то же время в Его проницающем мир действии ${ }^{3}$ : «вяя , Свят, Свят Господь Саваоф! Вся земля полна славы Его!» (Ис 6:3). Отсюда для еврейского народа вытекала необходимость жить в отдаленности от других народов и от мира, как „царство священников”, „народ святой”, чтобы в окончательном счете привести весь мир к Его воле ${ }^{4}$. Ветхозаветное определение святости заключалось в ее тесной связи со святостью Божьей. Любая человеческая святость являлась откликом и приобщением к этой божественной святости.

В Новом Завете термин кадо́m был представлен несколькими греческими эквивалентами: агиотис

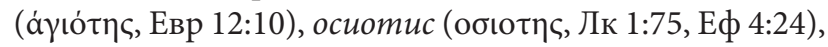

\footnotetext{
Ссылки на Священное Писание приводятся по: Библия. Книги Священного Писания Ветхого и Нового Завета, Mikkeli 1990.

2 А. Мень, Библиологчческий словарь, Москва 2002, Т. 3, с. 88.

A. Khoury, Leksykon podstawowych pojęć religijnych, Warszawa 1998, c. 1042.

4 Там же.
}

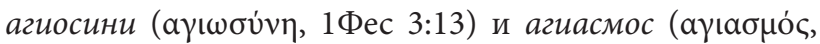
1 Фес 4:4). Значение данной семантической группы, сосредоточенной вокруг прилагательного аүı́є, было схоже с древнееврейским кадош, однако приобрело дополнительную окраску. Митрополит Ювеналий обращает особенное внимание на три аспекта, связанные с упоминанием о феномене святости в Новом Завете. Во-первых, термин святой в Новом Завете присущ именно Богу; во-вторых, данное слово часто относится к Христу; и, в-третьих, непосредственно к христианам, именуемым святыми (á водные от слова аүı́́, обозначают соответственно: агиотис - качество святости, агиосини - состояние святости и агиасмос - результат святости 5 . Анализируя семантическое значение слова святость, представленное Священным Писанием семитским словом קғ: , древнегреческим аүı́ь и латинским sanctitas, можно сделать первые выводы о сути данного явления.

В библейском понимании феномен святости является частью божественного откровения, Бог являет себя человеку, открывает ему Свою святость: «Это вода Меривы, у которой вошли в распрю сыны Израилевы с Господом, и Он явил им святость Свою» (Чис $20: 13)$. Одновременно она является проявлением трансцендентности Бога, Его силы, уничтожающей все недостойное, стремящееся к ней приблизиться: И поразил Он жителей Вефсамиса за то, что они заглядывали в ковчег Господень (1Цар 6:19). И все же божественная святость не отождествляется ни с могуществом, ни с трансцендентностью, поскольку она проявляется также в любви и всепрощении: «Не сделаю по ярости гнева Моего, не истреблю Ефрема, ибо Я Бог, а не человек; среди тебя Святыци» (Ос 11:9). Святость является исключительно божественной чертой, тем, что выводит за рамки творения - видимого и невидимого мира 6 .

Хотя термин „святость” в полном объеме может быть употребляем лишь к Богу, можно говорить о святости вещей и человека, с которым Он соприкасается. Новый Завет раскрывает святость в Иисусе Христе, в Его Церкви и верующих людях. Участие в святости верующие имеют благодаря посредничеству Спасителя и действии Святого Духа ${ }^{7}$, являющегося источником святости ${ }^{8}$. Важно отметить, что библейское понимание святости достаточно объемно. Святость в Библии это не просто отказ от мирского, это ответ на божественное откровение, восхождение человека к Богу источнику святости. Проблема природы святости, затрагиваемая Священным Писанием, в конечном итоге сводится к божественной тайне и ее таинственному откровению.

Семантическая и предметная характеристика святости, данная Священным Писанием, потребовала дополнительного богословского осмысления для окончательной интерпретации данного феномена. Перед тем,

\footnotetext{
Канонизации святых, Троице Сергиева Лавра 1988, с. 3-4.

Канонизации святых, с. 4-7.

A. Zelek, Czym jest świętość?, Ząbki 2005, c. 17-18.

Św. Augustyn, Wyznania, Warszawa 1955, c. 243.
} 
как приступить к рассмотрению религиозно-философских трактовок феномена святости, уместным будет провести этимологически-семантическую оценку данного концепта в контексте русского языка.

Полный церковно-славянский словарь, анализируя происхождение слова святость, концентрируется на корне свят, и относит его происхождение непосредственно к санскритскому глаголу с̧vi (блестеть, сиять). В то же время прилагательное çvinta (или çvênta) подразумевает святого, в буквальном переводе - сияющего, очищающего. Согласно данному словарю, славянское прилагательное, содержащее в себе корень свят, на Руси имело одинаковое значение и первоначально, в дохристианскую эпоху, было тождественным понятием с прилагательным сильный, крепкий, рослый, и лишь позже приобрело дополнительное значение светлый, сияющий, незапятнанный 9 .

Несколько иную позицию занял Владимир Топоров, усматривающий в основе слова „святость” праславянский элемент svęt, связывающий теперешнее русское прилагательное святой с индоевропейской основой $k^{\prime}$ uen-to (возрастание, набухание, вспухание) ${ }^{10}$. Как доказательство такой точки зрения, исследователь приводит факт использования славянами эпитета святой в качестве символа вегетативного плодородия (святое дерево, роща, жито), животного плодородия (святая пчела, корова), а также сакрально отмеченных точек пространства и времени (святая гора, поле, камень $)^{11}$. Все это дает право утверждать о глубокой дохристианской семантической наполненности и бесспорной сакральности данного термина еще в языческую эпоху. Исследователь провел детальный анализ функционирования понятия святость в русской духовной культуре и представил собственное видение данной проблемы следующим образом:

«Прежде всего, нужно напомнить, что само понятие святости (как и соответствующее слово), столь существенное в христианстве, в частности, в православии и еще уже - в русской церковно-религиозной традиции, гораздо древнее христианства и времени сложения русского языка. [...] Говоря в общем, сакральность (или даже гиперсакральность) древнерусской литературной традиции проявляется, главным образом, в том, что 1) все должно быть в принципе сакрализовано, вырвано из-под власти злого начала - и - примириться с меньшим нельзя - возвращено к исходному состоянию целостности, чистоты» ${ }^{12}$.

В то же время современные словари русского языка рассматривают термин „святость” с социологической

Г. Дьяченко, Полный Церковно-славянский словарь, Москва 1998, с. 584; Полный православный богословский энииклопедчческий словарь, Лондон 1971, Т. 2, с. 2015.

10 В. Топоров, Святость и святье в русской духовной культуре, Т.1, Москва 1995, с.7-9.

11 Там же.

12 Там же. точки зрения, устанавливая значение имен существительного и прилагательного „святой”. Так, толковый словарь Б. Волина и Д. Ушакова рассматривает несколько семантических групп, характеризующих данный термин. В религиозных представлениях святой обладает абсолютным совершенством и чистотой, является праведным, непорочным, отвечающим религиозному идеалу. В христианском культе - это «человек, проведший свою жизнь в защите интересов церкви и религии и после смерти признанный непререкаемым образцом христианской жизни и покровителем верующих», а также «наделенный божественной благодатью, являющийся источником божественной силы» ${ }^{13}$. Святой является лицом проникнутым „чем-нибудь высоким, возвышенным, идеальным” ${ }^{4}$. Тот же подход к определению значения слова „святой” мы найдем в толковом словаре Сергея Ожегова и Наталии Шведовой ${ }^{15}$.

Достаточно широкую трактовку данного термина представляет в своем словаре Владимир Даль, который определяет святого как высоконравственного человека - непорочного, чистого и совершенного. Наряду с этим исследователь рассматривает также абстрактное понятие святого как объекта принадлежащего к сфеpe sacrum: «все, что относится к Божеству, к истинам веры, предмет высшего почитания, поклонения нашего, духовный, божественный, небесный» ${ }^{16}$. В словаре Даля представлена также неполная типологизация разрядов святых.

На наш взгляд, наиболее обширное толкование термина святость дает Словарь современного русского литературного языка, выделяющий восемь семантических полей:

«1. По религиозным представлениям - исполненный святости; божественный. [...] 2. Связанный с религиозным поклонением (обычно употребляется как постоянный эпитет предметов и мест религиозного поклонения). [...] 3. Относящийся к Пасхе, имеющий место в Пасху, происходящий на Пасху. [...] 4. Только в полной форме. В христианской религии - проведший жизнь в служении Богу и признанный церковью после смерти покровителем верующих. [...] 5. Перен. Высоконравственный, безупречный в своей жизни, поведении и т.п. [...] 6. Глубоко чтимый, дорогой, заветный. [...] 7. Нерушимый, незыблемый. [...] 8. Чрезвычайно важный, высокий, почетный. [...]» ${ }^{17}$.

Как видно из цитаты, автору словарной статьи полностью удалось охватить смысловое религиозное

Б. Волин, Д. Ушаков, Толковый словарь русского языка, Москва 1940, T. 4 , с. 110

14 Там же.

15 С. Ожегов, Н. Шведова, Толковый словарь русского языка, Москва 1999, с. 705

16 В. Даль, Толковый словарь живого великорусского языка, Москва 2001, T. 4, c. 161.

17 Словарь современного русского титературного языка, ред. А. Бабкин, Москва-Ленинград 1962, Т. 11, с. 468-472. 
поле исследуемого термина. Содержательная характеристика святости в Словаре современного русского титературного языка была представлена на основании таких устоявшихся понятий и словосочетаний в русском языке как: святой/ые, приобщение Святых Тайн, Святое писание, Святая неделя, Святая Святых, святая икона, святая книга, святые слова, святой отеи, святой угол, святые места ${ }^{18}$.

Современное понимание прилагательного „святой” и его употребление в религиозно-церемониальной практике произошло намного позже. Согласно энциклопедическим данным, в памятниках христианской древности до середины IV века как у восточных, так и у западных христиан слово святой (aүı́,, sanctus) не отождествлялось с сегодняшними канонизированными святыми и вообще употреблялось довольно редко. По мнению некоторых ученых, причина избегания первыми христианами эпитетов sanctus, sanctissimus заключается в их отождествлении с языческим прошлым. Поэтому вместо этого названия часто при имени почитаемого церковью лица стояло - dominus, domini, что в свою очередь ассоциировалось с сегодняшним понятием мученик ${ }^{19}$. Этот факт вызван скорее всего тем, что в первые века христианства главным путем достижения святости было именно мученичество.

Стоит отметить, что сам термин „святость”, абстрагированный от свойств конкретного носителя и оформленный в существительное с абстрактным признаком, возник лишь в начале ХХ века ${ }^{20}$. До этого времени святость, определяемая исключительно сквозь призму Священного Писания, ассоциировалась с конкретным носителем, - Богом и святыми. Как следствие, данное явление стало рассматриваться не только с социологической точки зрения, т.е. с точки изучения фигуры и значения конкретного святого в жизни общества, но и как феноменологическое явление, т.е. особого рода переживания.

Вне всякого сомнения, семантика русского концепта святости не отражает всей совокупности явлений, с ним сопряженных. Данный феномен в большой степени связан с религиозным опытом, личными переживаниями конкретного христианина. Апофатичность раннего богословия была вызвана, в частности, невозможностью передачи мистических откровений с помощью языкового инструментария. Отсюда вытекает необходимость невербального представления трансцендентного мира. В православном богословии икона выступает не только как изображение духовных явлений, но и как дверь или окно, соединяющее два мира ${ }^{21}$.

В православно-богословской трактовке, святость является фундаментальным понятием и стоит в не-

\footnotetext{
18 Там же.

19 Христианство. Энциклопедический словарь, ред. С. Аверинцев, А. Мешков, Москва 1995, Т. 2, с. 527.

20 С. Климова, Феноменология святости и страстности в русской философии культурь, Санкт-Петербург 2004, с. 31.

21 См. дет.: Л. Успенский, Богословие иконь Православной Церкви, Москва 2007.
}

посредственной связи с идеей теозиса ( $\theta \dot{\varepsilon} \omega \sigma \iota \varsigma)$ или обожения, преображения человека под воздействием Божественной благодати. Мера святости конкретного человека это и есть мера его обожения и наоборот. Судя по всему, Отцы Церкви в своих богословских трактатах не употребляли слишком часто термин святость и не занимались ее детальным анализом, поскольку руководствовались наработанной библейской трактовкой, концентрируясь больше на самом процессе достижения святости, суть которой являлась для них априорной. В святоотеческих трудах содержится психологическое понимание человека и практический опыт достижения святости.

Только Бог обладает таким качеством как святость. Он - источник всей христианской святости. Он свят по Своей сути, отмечает Кент Брауер, известный исследователь проблематики святости ${ }^{22}$. Человеческая же святость является производной от Божьей святости.

Поскольку для Святых Отцов святость, вслед за библейским пониманием, являлась исключительной прерогативой трансцендентного Бога, то логично, что ее достижение может осуществляться единственно посредством богообщения, приобщения человека к божественной благодати по мере очищения от страстности природы:

«[...] освящение есть полнейшая неподвижность и умерщвление чувственной похоти. Находясь в таком состоянии, мы унимаем непристойный вой ярости, не имея более похоти, возбуждающей ее, а также подстрекающей ее воевать из-за своих наслаждений. А поэтому похоть, благодаря сообразной с разумом святости, умерщвляется в нас» -

писал преподобный Максим Исповедник ${ }^{23}$. Св. Иоанн Кассиан, в свою очередь, описывая настоящую борьбу со страстями, пользовался характеристикой святости, данной апостолом Павлом:

«Вот воля Божья, говорит св. Павел - святость ваша. И чтобы не оставить в нас сомнений и темного непонимания, что именно называет он святостью, - правду, любовь, смирение или терпение, поскольку этими добродетелями и достигается святость; он прямо определяет, что именно хотел назвать святостью: Вот воля Божья - святость ваша: чтобы вы воздерживались от блуда. Чтобы каждыци из вас умел соблюдать свой сосуд в святости и чести, а не в страсти похоти, как язычники, не знающие Бога» ${ }^{24}$.

В конце борьбы христианину готовится упокоение в Божественной святости:

«И мы теперь испытываем побуждение делать

\footnotetext{
22 К. Брауер, Святость в евангелиях. Возвращение к библейскому представлению о святости в XXI веке, Санкт-Петербург 2009, с. 12.

23 Творения преподобного Максима Исповедника, Москва 1993, кн. I, http://www.krotov.info/acts/07/2/ isp _ 1_185.html, информация от 10.07.2008 г.

24 Добротолюбие, Т. 2, Свято-Троицкая Сергиева Лавра 1992, с. 39.
} 
добро, после того, как сердце наше зачало от Духа Твоего мысль об этом; раньше нас, покинувших Тебя, подвигало на злое; Ты же, Господи, Единый, Благой, не прекращал творить добро. И у нас есть, по милости Твоей, некие добрые дела, но они не вечны. Мы надеемся, однако, что, закончив их, мы отдохнем в Твоей великой святости» ${ }^{25}$.

Вышеприведенные изречения Отцов Церкви лишний раз подтверждают априорность святости, как божественного свойства, описание которого богословскими терминами не представлялось необходимым. Богопознание осуществлялось первыми христианскими подвижниками чувственно, на основании личного духовного опыта, являвшегося интимной сферой каждого подвижника. Для отцов церкви теозис это «не идея, не теория, не догма, а прежде всего и более всего - факт их внутренней жизни» ${ }^{26}$. И все же некоторые богословы делились своим религиозным опытом. Одним из них был Симеон Новый Богослов:

«Я часто видел свет, и иной раз он являлся внутрь меня, когда душа моя имела мир и тишину, а иной раз являлся он вне вдали, или даже совсем скрывался, и когда скрывался, причинял мне чрезмерную скорбь [...] Но когда я начинал плакать и проливать слезы, и показывать всякую отчужденность от всего и всякое послушание и смирение, тогда он являлся опять, как солнце [...] Так наконец Ты, неизреченный, невидимый, неосязаемый, приснодвижный, везде, всегда и во всем присущий и все исполняющий, видимый и скрывающийся каждый час [...] прогнал бывшую во мне тьму, рассеял покрывавший меня облак, очистил зеницу умных очей моих, открыл душевный слух мой, снял покрывало нечувствия с сердца моего, и вместе с сим усыпил плотскую сласть и совсем изгнал из меня всякую страсть. [...] О неизреченное снисхождение!» ${ }^{27}$.

В данном лицезрении Божественного света Владимир Лосский усматривает проявления наивысшего познания благодати и свидетельство единения человеческой личности с Богом ${ }^{28}$.

В процессе восхождения к святости, христианин нуждается в детальном руководстве. Это связано с фактом сложной и требующей самоотречения аскезы,

\footnotetext{
25 Św. Augustyn, Wyznania, c. 343.

26 П. Минин, Главные направления древне-иерковной мистики, [в:] Мистическое богословие, Киев 1991, с. 339.

27 Слова прп. Симеона Нового Богослова, Москва 2001, с. 487-488.

28 Исследователь церковной мистики пишет: «Это уже более не экстаз, не преходящее состояние, которое восхищает, отрывает человеческое существо от его обычного опыта, но сознательная жизнь в свете, в непрестанном общении с Богом. [...] Божественный свет становится основой нашего сознания: в нем мы познаем Бога и познаем самих себя. Он проникает в глубины нашего существа, вступающего в единение с Богом, он становится для него Божьим судом до Страшного суда». В. Лосский, Очерк мистического богословия Восточной Церкви, [в:] Мистическое богословие, Киев 1991, c. $247-249$.
}

а также многими духовными опасностями, лежащими на этом пути. Поэтому Отцы Церкви основной уклон делали на детальное описание процесса борьбы и очищения. Основными вопросами в богословских трактатах являлись разделы о борьбе с чревоугодием, блудом, сребролюбием, гневом, печалью, гордостью, унынием, т.е. душевными страстями ${ }^{29}$. Исключением являются учения некоторых апологетов о любви, в частности, св. Максима Исповедника и преподобного Фалласия ${ }^{30}$, богословские трактаты о Божественных Именах, Небесной и Церковной Иерархии Дионисия Ареопагита ${ }^{31}$.

Вместе с тем, для полноценного участия в божественной святости одной духовной борьбы и собственных усилий христианина недостаточно. Центральным пунктом восхождения и утверждения в ней является таинство Евхаристии, соединяющей верующих во Христе в одно мистическое тело. Освящение человеческой природы в процессе приобщения к Святым Тайнам является главным условием спасения: «Если не будете есть Плоти Сына Человеческого и пить Крови Его, то не будете иметь в себе жизни» (Ин 6:53). В Евхаристии происходит установление Царства Божия уже в нашем конкретном историческом бытии.

«Понимание христианской общины как общины друзей Божьих, „святого народа” с наибольшей полнотой выразилось в литургической жизни древней церкви, поскольку именно Евхаристия была центром и основой этой жизни, основой культа и основой учения [...] Во время причастия вечность преображенного бытия (Царствия Небесного, пакибытия) реально присутствует во временном бытии, в земной жизни церковной общины» ${ }^{32}$.

Стоит заметить, что в первые века христианства отсутствовали богословские трактаты, содержащие учение о самой святости. Заинтересованность явлением и рост ее популярности наблюдается лишь в XIX веке. Это может объясняться несколькими причинами. Одной из них может быть отказ от созерцательного, действенного богословия, которое так удачно практиковалось в первые века христианства, в пользу схоластики. По этому поводу Симеон Новый Богослов внушает нам очень существенную мысль: покаяние и богословствование суть два разных процесса, причем первый должен предшествовать последнему, являющимся умственно-чувственным процессом - „состоянием созерцания", а не философией ${ }^{33}$.

\footnotetext{
29 Ср: учения св. Иоанна Кассиана, Нила Синайского, Ефрема Сирина, Иоанна Лествичника, Феодора Студита, Симеона Нового Богослова и др. Отцов Церкви.

30 См. дет.: Добротолюбие, Т. 3, с. 163-229, с. 290-318.

31 Pseudo-Dionysius Areopagita, O Imionach Bożych, Lublin 1995; Тот же, Pisma teologiczne, Kraków 2005; Тот же, Hierarchia niebiańska; Hierarchia kościelna, Kraków 1999.

32 В. Живов, Святость. Краткий словарь агиографических терминов, Москва 1994, http://avorhist.nar od.ru/help/sanct.htm, информация от 27.09.2008 г.

33 Он пишет: «Ни к тому, кто богословствует, не идет покаяние, ни к тому, кто кается, не идет богословствование. Ибо сколько
} 
В пользу утверждения о постепенном отходе христианских мыслителей от действенного созерцательного богословия в пользу схоластического философствования говорит приведенная Лосским цитата Св. Серафима Саровского:

«Мы в настоящее время [...] до того дошли, что почти не понимаем слов Священного Писания. Некоторые говорят: это место непонятно, неужели апостолы так очевидно Духа Святого чувствовать могли? Нет ли здесь ошибки? Но ошибки... не было и нет никакой... Это все произошло оттого, что, мало-помалу удаляясь от простоты христианского ведения, мы под предлогом просвещения зашли в такую тьму неведения, что нам кажется уже совсем непонятным то, что для древних христиан было ясностью и что в самых обыкновенных разговорах понятие о явлении Бога между людьми никому из собеседников не казалось странным» ${ }^{34}$.

Соответственно, чем меньше человек ощущает божественную святость, погружается в нее, тем больше нуждается в ее интеллектуальном, философском осмыслении. Однако, несмотря на незначительное присутствие термина „святость” в трудах ранних и средневековых христианских богословов, можно все же говорить о богословии святости, центральным пунктом которого, как мы уже сказали, является учение о теозисе.

Наряду с православно-богословской трактовкой идеи святости существенную категорию представляет понимание данного феномена религиозными и философскими мыслителями Запада и Востока. Среди философов, занимающихся рассмотрением данного явления, на первое место выдвигается основатель феноменологии религии, протестантский богослов и религиовед - Рудольф фон Отто. В своей книге Das Heillige, изданной в 1917 году, Отто впервые в истории христианской философии рассмотрел категорию святости как религиозный феномен со всеми вытекающими из этого последствиями. Интересно, что в русскоязычной литературе название книги переведено как Священное, в то время как в польском языке фигурирует название Святость, представляющееся нам более правильным вариантом перевода.

Итак, в начале своих размышлений Отто проводит разграничение рационального и иррационального

отстоит восток от запада, столько богословие выше покаяния. Кто находится в состоянии покаяния и воистину творит дела покаяния, тот себя являет как человек больной, день за днем проживающий среди изнемоганий, или как бедный, одетый в рубища и просящий милостыню. А кто богословствует, тот походит на человека, который проводит время в царских палатах, в светлом царском уборе, всегда находится близ царя, беседует с ним и от него самого слышит ясно повеления его и все, чего он хочет (разумеется, состояние созерцания, а не научное богословствование)». Добротолюбие, Т. 5, c. 45. Ср.: 1Кор 3:19.

34 Цит. по В. Лосский, Очерк мистического богословия Восточной Церкви, [в:] Мистическое богословие, с. 247. элемента в познании божества. Для философа нет никакого противоречия в существовании данной антиномии, являющейся, по сути, двумя разными путями познания божественной реальности - т.е. умственного (рационального, описывающего все с помощью дефинитивных определений) и чувственного (познающего трансцендентную реальность чувственными рецепторами) $)^{35}$. Данная мысль проходит сквозь всю систему взглядов протестантского богослова, ее центральным пунктом является утверждение о том, что, несмотря на всю необходимость существования рационального элемента, на высшем уровне мистического опыта одного разума для богопознания становится недостаточно. Святость является именно таким феноменом, - недоступным для понятийного постижения и ускользающим от рационального мудрствования, это неописуемое явление (arreton ineffabile) ${ }^{36}$.

Тем не менее, на уровне рационального дефинирования познание святости все же возможно. Р. Отто также исследует этимологию слова святость и упоминает о его первоначальном библейском происхождении. Однако, по мнению философа, современное понимание данного слова приобрело неправильную семантическую направленность, а именно ассоциативность с нравственной атрибутикой. Отто четко дистанцируется от нравственного редукционизма, переводя святость из области морального совершенствования совсем в иную плоскость - в плоскость религиозных переживаний ${ }^{37}$. Отсюда, по мнению философа, существует необходимость в новом лексическом оформлении термина святость в новый - numinosum (нумен, нуменозный от лат. numen - божество) ${ }^{38}$. Сoгласно Отто, нуменозность является центральным атрибутом духовного опыта, встречей человеческой личности со Святым, сверхразумным переживанием божества, которые нельзя отождествить ни с одной из человеческих эмоций. К религиозной реальности человек может приблизиться благодаря особенной власти, т.н. semsus numinis, через внешнее и внутреннее соприкосновение со священным (sacrum $)^{39}$.

Переживание нуменозности или соприкосновение с ней сопряжено с другими важными чувствованиями. Отто вводит несколько категорий таких переживаний. Первым из них является чувство тварной зависимости (тварности), проявляющееся в осознании личностью своего ничтожества в сравнении со своим Создателем. Одним из условий его возникновения является реальность контакта с нуминальным объектом ${ }^{40}$. Второе переживание немецкий феноменолог определяет как mysterium tremendum или чувство мистического страха. Данная категория вытекает как из внутренних душевных переживаний, так и из божественной атри-

\footnotetext{
35 R. Otto, Świętość, Warszawa 1999, c. 5-7.

36 Там же, с. 9.

37 Z. Zdybicka, Człowiek i religia, Lublin 2006, c. 238.

38 R. Otto, Świętośćc, c. 10.

39 Z. Zdybicka, Człowiek i religia, c. 239.

40 R. Otto, Świętość, c. 15.
} 
бутивности, носящей не только позитивный (благость, любовь, великодушие), но и негативный характер (гнев, ярость). Причем последнее божественное свойство всегда оправдано всевидящей справедливостью ${ }^{41}$. Противоположным чувством mysterium tremendum является fascinans - чувство влечения, зачарованности и восхищения. Numinosum одновременно отталкивает и привлекает, парализует и очаровывает, вызывает мистический ужас и восторг, образуя т.н. контраст-гармонию. На определенном этапе религиозного опыта mysterium tremendum и fascinans являются уже чем-то одним, нераздельным. Философ обращает внимание на эволюционность переживания numinosum, на начальной стадии которой мы имеем дело с демоническим страхом, а в конце - с божественным трепетом.

Анализируя эволюционность переживаний нуменозного в Ветхом и Новом Завете, Отто приходит к выводу о процессе постепенной рационализации numinosum. Однако, ошибочным было бы полагать, что данная рационализация исключает или опровергает numinosum. Подтверждением такого взгляда является факт ключевой евангельской проповеди - проповеди Царства Божьего, являющегося чисто нуменозным объектом. В Царстве Божьем все проникнуто мистицизмом, все является нуменозным. В данной реальности термин „святые” является лишь нуменозным техническим термином. Хозяин и владыка данного Царства это Бог-Отец, который является воплощением всей выше изложенной нуменозности с ее контраст-гармонией. Отождествляя Отца исключительно с позитивными рационализаторскими атрибутами, наука утрачивает, считает Отто, истинный библейский смысл, как данного существительного, так и его определения:

«Będąc jego (царства - 3.К.) władcą, jest on nie mniej święty, numinotyczny, tajemniczy, kadosz, hagios, sacer, i sanctus niż jego królestwo, lecz jeszcze bardziej, i to w stopniu absolutnym, jest sublimacją i dopełnieniem tego wszystkiego, co Stary Testament mówi o „uczuciu zależności stworzenia”, o „świętej bojaźni” itp.» ${ }^{42}$.

В Новом Завете не было необходимости еще раз повторять учение о страхе Господнем и божественном всемогуществе, поскольку в сознании израильтян данный факт уже являлся аксиомой. Христос проповедовал новое знание, которое надлежало усвоить, а именно, что тот же неприступный, всемогущий и приводящий в трепет Бог, является одновременно благим и всемилостивым Отцом Небесным. Данный контраст неприступности и близости, гнева и милосердия, мощи и благости, силы и кротости является стержне-

\footnotetext{
41 Согласно Отто, mysterium tremendum можно наблюдать уже в языческих религиях в виде физиологических проявлений, как то телесное остолбенение, судорожное состояние тела, которое на высших этапах развития религии проявляется уже в более утонченном и обостренном виде - столбенеет уже не тело, а душа и ее таинственные органы. R. Otto, там же.

42 R. Otto, Świętość, c. 102.
}

вым христианским чувством. В конечном счете, процесс рационализации не приводит к опровержению нуменозного, а, наоборот - к его дополнению. На основании приведенных религиоведческих исследований Р. Отто приходит к выводу о сути феномена святости. Он констатирует:

«Świętość w pełnym znaczeniu tego słowa jest więc dla nas kategorią złożoną. Składające się na nią elementy stanowią jej racjonalne i irracjonalne części składowe. Co do obydwu elementów jest ona jednak - co należy podkreślić $\mathrm{z}$ całą mocą wbrew wszelkiemu sensualizmowi i wszelkiemu ewolucjonizmowi - czystą kategorią a priori» ${ }^{43}$.

Так понимаемая святость обладает свойством как внутреннего, так и внешнего проявления. Феноменолог не случайно затрагивает этот вопрос. Одним из ключевых условий адекватного контакта с нуменозным религиовед считает способность правильного познания и распознания святости в ее проявлениях, определяемую им как дар видения (divination). На языке Священного Писания эта способность называется „внутренним свидетельством Святого Духа”44. Рассматривая данное свойство человеческой психики, Отто руководствуется пониманием Фридриха Шлеймахера, однако, в отличие от последнего, развивает понимание данной способности в христологическом направлении. Для Отто именно Христос является высшим проявлением святости, ее зримым воплощением.

Спонтанность проявления связана со спонтанностью дара видения, считает религиовед. Учение Христа не было учением о себе самом, а о Царстве Божьем. Следовательно, утвердительное заключение учеников: „Ты Христос, Сын Бога Живого” (Мф 16:16), вытекало из дара видения святости, а не из рационалистических выводов, сделанных на основании проповедей Спасителя. Святость в данном случае является тем иррациональным фактором, который влечет и пленит сердца верующих. Благодаря данному рассуждению раскрывается механизм притягивания к себе святых, вокруг которых, как правило, всегда группируются и сосредоточиваются ученики, последователи, поклонники. Святость - истинный центр притяжения, а мера приобщения к ней, - это мера духовного роста и развития.

Окончательное оформление проявления святости во Христе произошло на Кресте. В Кресте Спасителя сочетаются элементы рационального и иррационального, того что можно постичь и чего постичь не возможно. Крест - это не просто отражение Предвечного Отца, не просто отражение наивысшего рационального элемента святости, а святости как таковой.

Анализ религиозного феномена, проделанный Отто, встречается с некоторой критикой польской исследовательницы в данной области Софии Здыбицкой, которая вслед за Стружевским не находит в тру-

\footnotetext{
43 Там же, с. 133.

44 Там же, с. 167.
} 
де немецкого религиоведа ответа на главный вопрос о самом факте существования нуменозного и, таким образом, о возможности отнесения его к метафизическому смыслу. Однако, существует ли необходимость феноменологического обоснования существования божественного начала, и ставит ли перед собой сам немецкий религиовед такую цель? Применительно к данной книге, с уверенностью можно утверждать, что нет. Отто неоднократно упоминает о первопричинности религиозного опыта, который, как мы уже показали выше, является для него априорным. Сам же ученый в начале своей книги дает определение аудитории своего труда $^{45}$.

Философско-религиоведческие изыскания феномена святости Р. Отто были продолжены в трудах нескольких поколений религиоведов и феноменологов. Одними из главных в данной области являются труды румынского исследователя Мирчи Элиаде. С точки зрения изучения феномена святости нас будут интересовать Священное и мирское (1956 г.) и Трактат по истории религий (1948 г.), где были представлены главные результаты феноменологического и исторического изучений фактов религиозного опыта.

Для Элиаде основным элементом в понимании феномена святости является разграничение реальности на сферу sacrum и profanum. На основании данного разграничения Элиаде строит свое учение, где первым ключевым определением святости и священного является ее противоположность сфере светскости ${ }^{46}$. Вторым важным определением является понятие иерофании (греч. เєро́ - священный и фаvó - свет), которое Элиаде понимал как воплощение или проявление святости в мире:

«Można by stwierdzić, że historia religii [...] składa się z dużej liczby hierofanii, to znaczy objawień rzeczywistości świętych. Od hierofanii najbardziej podstawowej (na przykład objawienia się świętości w jakimś przedmiocie - kamieniu czy drzewie) do hierofanii najwyższej (którą dla chrześcijanina jest wcielenie się Boga w Jezusa Chrystusa) biegnie nieprzerwanie kontinuum. Zawsze stoimy naprzeciwko tego samego tajemniczego procesu: „całkiem inne”, rzeczywistość nie z tego świata, przejawia się w przedmiotach, które są integralnymi częściami składowymi naszego "naturalnego”, „świeckiego" świata» ${ }^{47}$.

Проявление сакральности в вещах, предметах, явлениях относится к сфере внутреннего, духовного восприятия. Новое измерение святости, раскрывающееся в конкретном объекте, становится доступным лишь в религиозном опыте. Человеку свойственно в большей или меньшей степени стремление к религиозности мировосприятия, наивысшей стадией которого является

\footnotetext{
45 К такой аудитории должен принадлежать человек, обладающий, по крайней мере, минимальным религиозным опытом. См. R. Otto, Świętość, c. 13.

46 M. Eliade, Sacrum i profanum, Warszawa 1996, c. 6-7.

47 Там же.
}

вселенская сакральность, где Космос предстает как всеобъемлющая иерофания. Стремление к религиозности, и соответственно, сакрализированности окружающей действительности, наблюдается, согласно исследователю, в наибольшей степени в архаическом обществе. Объясняется это, прежде всего, отождествлением святости с силой, а в конечном результате с самой действительностью:

«Człowiek żyjący w społeczeństwach archaicznych przejawia usiłowanie, by żyć $w$ tym, co święte lub w bezpośredniej bliskości poświęconych przedmiotów. Usiłowanie to jest zrozumiałe, albowiem dla ludzi „pierwotnych”, jak również dla wszystkich społeczności przednowożytnych, świętość oznacza tyle, co siła, a ostatecznie także po prostu rzeczywistość. [...] Święta siła oznacza tyle co rzeczywistość, wieczność i skuteczność w jednym. Przeciwieństwo święte - świeckie często jawi się jako przeciwieństwo między rzeczywiste i nierzeczywiste lub pseudorzeczywiste» ${ }^{48}$.

Из этого постулата ученый делает заключение о существовании двух форм пребывания в мире - peлигиозной и светской. Современное общество, отличающееся светскостью мироощущения, пребывает в десакрализированной действительности. В отличие от религиозного человека, стремящегося пребывать в „святом Универсум”, десакрализированный светский человек весь свой быт сводит лишь к органическому, физиологическому функционированию, отрицающему трансцендентное и одобряющему „относительность” реальности. Характерным моментом для данного понимания сакральности и десакрализированности является то, что религиозное функционирование не опровергает физиологию, но лишь усматривает в ней другое, „дополнительное” измерение. Homo religiosus, по мнению Элиаде, это онтологическое свойство человеческой личности, вытекающее из определенных до конца не исследованных фундаментальных фактов ${ }^{49}$.

Склонность к религиозности обуславливается, как считал религиовед, не только внутренними, но и внешними факторами. Уже в само творение, порядок Вселенной, отображающий своим благоустройством некоторые проявления священного, предрасполагал человеческое сознание к религиозности.

«Świat został stworzony w taki sposób, że człowiek religijny, patrząc nań, odkrywa różnorodne formy przejawu sacrum, tym samym zaś bytu. Przede wszystkim: świat istnieje, jest tu oto i ma jakąś strukturę; nie jest on chaosem, lecz Kosmosem; [...] Owo boskie dzieło zawsze znamionuje niejaka przejrzystość, spontaniczne odsłania ono różnorodne aspekty świętości. Niebo bezpośrednio i „naturalnie” objawia nieskończoną dal, transcendencję Boga. [...] Kosmos jako całość jest

\footnotetext{
48 Там же, c. 8.

49 Z. Zdybicka, Człowiek i religia, c. 243.
} 
organizmem zarazem realnym, żywym i świętym: objawia on modalność bytu i sacrum» ${ }^{50}$.

Сакральность космического строения стала причиной появления многих форм религиозных культов практически у всех этносов. Элиаде классифицирует разновидности религиозных служений и божеств в зависимости от объекта космического порядка. Небосвод, Земля, а также такие стихии как вода и огонь вызвали к жизни большое количество культов, направленных на их богопочитание ${ }^{51}$. Из этого исследователь делает вывод о фундаментальной общности всех верований и религий, отображающих по сути одну и ту же божественную реальность.

На основании анализа трудов М. Элиаде, можно сделать главные выводы о его видении феномена святости. На первый план выдвигается разница в подходе к данной проблеме с Р. Отто. Если немецкий феноменолог акцентировал свое внимание, прежде всего, на иррациональной природе святого, являющегося «абсолютно и полностью отличным: не похожим ни на человеческое, ни на космическое», то Элиаде имеет другой подход к опыту святого. Mysterium tremendum и mysterium fascinans уступают место другому нуменозному опыту - чувству полноты божественного бытия. В столкновении с нумен человек не столько ужасается, сколько находит для себя „центр ориентирования”, „пуп земли”, imago mundi $i^{52}$. В религиозном опыте человек открывает для себя знак, обладающий религиозным значением, который вносит в его жизнь умиротворенность и извлекает его из „относительности и путаницы”. Идея „страшного Бога” чужда Элиаде - чувство страха возникает лишь у непосвященных.

Феномен святости Элиаде относит к онтологически объективной, абсолютной реальности.

«Świętość to $[\ldots]$ po prostu rzeczywistość, to moc, siła oddziaływania, źródło życia i płodności. Pragnienie człowieka religijnego, by wieść życie $\mathrm{w}$ świętości, to pragnienie życia w rzeczywistości obiektywnej, [...] to pragnienie życia $\mathrm{w}$ świecie prawdziwym i zdolnym do oddziaływania, nie w świecie iluzorycznym. Tęsknota ta znajduje najsilniejszy wyraz w potrzebie człowieka religijnego, by żyć $\mathrm{w}$ świecie uświęconym, a więc w przestrzeni świętej» ${ }^{53}$.

Святое, как было показано выше, проявляет себя в мире в чувственно доступной человеку форме - иерофании. В основе природы человека, в свою очередь, заложено интуитивное стремление к святости. Ното religiosus составляет одно из главных свойств его личности. Поэтому иерофания является ничем иным, как ответом на вопросы человеческой души, желанной встречей трансцендентной реальности с личностью. Человек сам стремится стать таким же „иным”, как об-

\footnotetext{
50 M. Eliade, Sacrum i profanum, c. 95.

51 Сравни: там же, с. 95-131.

52 M. Eliade, Sacrum i profanum, c. 34; M. Eliade, Traktat o historii religii, Warszawa 2000, c. 395

53 Там же, с. 22.
}

наруженная им иерофания. Предмет, в котором проявилась иерофания, становится сакральным, но не перестает при этом быть самим собой, поскольку продолжает существовать в космическом пространстве.

В практическом плане или анализе проявлении плодов святости данный феномен рассмотрел американский философ и психолог, один из основателей прагматизма и функционализма - Уильям Джеймс. В своей книге The Varieties of Religious Experience исследователь осуществил попытку не только дать определение состояния святости, но и выделить главные черты и душевные состояния человека, достигшего того или иного уровня святости. Джеймс определяет состояние святости как наитие свыше, возрождение души, проявляющееся в определенном психо-духовном состоянии человека, характеризующемся любовью и смирением, безграничным доверием к Богу, строгостью к себе, снисходительностью к другим.

Ценностью исследования американского философа с перспективы данной работы является систематизация состояний святости и характеристика отличительных свойств просветленного человека. По мнению Джеймса, поступки человека в большей или меньшей степени зависят от его эмоциональной восприимчивости, суть которой исследователь усматривает в дуализме запрещающих и утверждающих установок психики. Благодатное состояние снимает с человеческой психики все сдерживающие ее психологические факторы и выводит человека на новый уровень восприятия действительности ${ }^{54}$.

Как верно заметил исследователь, святым свойственна непрерывность состояния экзальтации и умиленного настроения, в то время как человек, не достигший высокого уровня религиозно-мистического опыта, может испытывать данные чувства лишь изредка, а иногда только раз в жизни.

Согласно Джеймсу, святостью можно назвать созревшие плоды религиозного состояния. Несколько иначе, святым человеком можно назвать того, кто в своей деятельности руководится религиозным чувством. На этом основании философ пытался сформировать общий для всех религий тип святого со свойственными ему отличительными чертами. Итак, по мнению ученого, святого отличает: 1. ощущение более широкой жизни и убеждение в существовании Верховной Силы, достигнутое путем непосредственного чувства. Для христианских святых олицетворением этой Силы всегда является Бог; 2. чувство интимной связи между верховной силой и нашею жизнью и добровольное подчинение этой силе; 3. безграничный подъем и ощущение свободы, соответствующее исчезновению границ личной жизни; 4. перемещение центра эмоциональной жизни по направлению к чувствам, исполненным любви и гармонии ${ }^{55}$. Кроме основных черт

\footnotetext{
54 W. James, Doświadczenia religijne, przeł. J. Hempel, Kraków 2001, c. 209.

55 Там же, с. 213
} 
типичного святого философ выделяет четыре главных свойства душевного состояния такого человека: аскетизм, сила души, чистота души, милосердие.

Минусом изысканий Джеймса является углубленный субъективизм описываемых переживаний, в котором душевные порывы относятся скорее к внутреннему „я”, чем действию благодати. Так, аскетизм становится способом измерения степени преданности высшей силе. Данный подход представляется совсем корректным лишь в известной степени. В частности, в отношении к восточным религиям. В христианстве же понимание аскетизма основано на иных принципах, ставящих на первое место укрощение плоти в борьбе со страстями, подготовку телесности к контакту с божественным началом. Отсюда потребность в чистоте духа, доходящая до аскетизма, является не первичной, а вторичной, вытекающей непосредственно из желания „вечного общения” с Богом.

Исследуя категорию святости в философско-религиоведческих трудах западных мыслителей, невозможно пройти мимо современных исследователей. Характерным примером в данной области является Луи Дюпре, профессор философии религии Йельского университета, который приобрел известность, в частности, благодаря своему труду по философии религии The other dimension. Основываясь на ключевых работах в данной области, трактатах о святости Р. Отто и М. Элиаде, Дюпре разработал собственный подход к феномену святости, учитывающий достижения современной философской мысли, ищущей «точки соприкосновения религии, морали и разума» и сосредоточенной на «интеллектуальном измерении религии» ${ }^{56}$.

Рассматривая ключевые положения философских размышлений о святости Л. Дюпре, стоит обратить внимание на первый аспект, которым для данного философа является утверждение о субъективности религиозного опыта и связанного с ним восприятия sacrum $^{57}$. Хотя ученый не отрицает существования трансцендентного источника - объекта религиозного опыта и, пользуясь терминологией Элиаде, признает существование „высшей действительности” или „окончательной реальности”, он ставит под сомнение собственную сакральность вещей. Для Дюпре, сакральность того или иного предмета относительна, поскольку ограничивается субъективностью восприятия конкретным человеком. Сакральность принадлежит лишь одному Абсолюту, точнее чему-то трансцендентно-сверхъестественному, которое проецирует ее в зависимости от предмета, вещи или явления.

«Do początkowego stwierdzenia potencjalnej religijności dowolnego przedmiotu możemy więc dołączyć stwierdzenie przeciwne, a mianowicie, że żaden przedmiot nie jest sakralny sam w sobie. Czynnikiem wyróżniającym sacrum jest fakt,

\footnotetext{
56 А. Буряковский, Глобализация и философия религии как прикладная дисциплина, [в:] Религия и нравственность в секулярном мире, Санкт-Петербург 2001, с. 79-82.

57 L. Dupré, Inny wymiar. Filozofia i religia, Kraków 2003, c. 17.
}

że absolut ukazuje się poprzez skończony przed$\operatorname{miot} »^{58}$.

Такой безличный источник святости и есть начало, реальная действительность, mana $^{59}$, отражающийся как в зеркале в конкретном сознании, или же не отражающийся вовсе ${ }^{60}$.

Очередным важным элементом в рассуждениях о святости Л. Дюпре является оппозиционность sacrum к profanum. Философ утверждает, что религиозная позиция диалектична, поскольку находится в соотношении (в оппозиции) с трансцендентным термином. Диалектическая противоположность sacrum и profanum приводит, в конечном результате, к „поглощению” profanum. „Окончательная действительность” стремится К преобразованию „относительной действительности” всей деятельности человека в религиозный ритуал. Характерно, что profanum это не альтернативное бытие, а вражеская деструктивная сила - „активное небытие”. Так понимаемое sacrum, согласно Дюпре, призвано играть консолидирующую роль, устраняя противоречия и интегрируя общество ${ }^{61}$.

Относительно постулированной оппозиционности sacrum к profanum умесно отметить, что согласно православной онтологии, любое диалектическое противопоставление в учении о бытии невозможно. Бог творит мироздание не из хаоса, а из небытия, т.е. того, что не существует, причем зло не является противоположностью добра, а его отсутствием. Юлия Дуплинская обращает внимание на то, что

«мира антиподов по отношению к Богу как единственному источнику всего сущего здесь нет. Бог является источником только бытия и только добра; ничего другого не существует. И зло, и безобразное, и даже бесы в христианской онтологии возникают не там, где есть что-то, а там, где что-то отсутствует, когда наш взор, вместо ожидаемого бытия, встречает его отсутствие [...]. Зло не является противоположностью добра, подобно тому, как тьма не является противоположностью света: существует только свет, а тьма - не противоположность, а отсутствие света - такова суть знаменитых рассуждений о зле Аврелия Августина» ${ }^{62}$.

На это обстоятельство обратил внимание также Владимир Лосский, согласно которому, зло не имеет природы, поскольку является лишь ее состоянием ${ }^{63}$.

\footnotetext{
58 Там же, с. 18.

Луи Дюпре употребляет данный термин в значении, данном Элиаде, который вслед за маланезийцами воспринимал тапа как таинственную и активную силу, являющуюся источником всех религиозных явлений. См. дет.: М. Eliade, Traktat o historii religii, c. $36-40$.

60 L. Dupré, Inny wymiar, c. 18.

61 Там же, с. 21.

62 Ю. Дуплинская, Христианство и метафизика зла, [в:] Литературно-философский журнал «Топос», 18 марта 2004 года, http:// www.topos.ru/article/2156, информация от 3.09.2008

63 В. Лосский, Очерк мистического богословия Восточной Церкви, [в:] Мистическое богословие, с. 178. Интересны также рассуждения на данную тему Псевдо Дионисия Ареопагита, см. дет.: Дионисий
} 
Самоутверждающим фактором sacrum является его божественное начало, а не оппозиционность к profanum. Задача священного - не „поглощать” мирское, а освящать бытие, приобщать к божественному, т.е. осуществлять цель спасения. Глобальная потенциальность святости вытекает не из глобальной способности sacrum „поглощать” и позиционироваться к profanum, а глобального „божественного присутствия”.

«Człowiek przyzwyczaja się do życia w świecie Bożym, w jego głębinach, czytając jego rajskie przeznaczenie, świat buduje się w liturgię kosmiczną, w świątynię chwały Bożej. Pozwala to zrozumieć, że wszystko potencjalnie jest świętością, że nie ma nic świeckiego, nie ma nic obojętnego, gdyż wszystko odnosi się do Boga» ${ }^{64}$.

Если profanum не является оппозицией к sacrum, то тогда чем оно является? Павел Евдокимов считает, что этой противоположностью является демоническая действительность - искажение божественной действительности ${ }^{65}$.

Рассматривая феномен святости в системе религиозно-философских воззрений, невозможно не затронуть мысль известного русского философа религии, Николая Бердяева. Его главной идеей, пронизывающей все концептуальное мировоззрение, была свобода духа, рассматриваемая в категориях экзистенциально-персоналистской философии. Суть своего понимания свободы Бердяев изложил в следующем высказывании:

«Своеобразие моего философского типа прежде всего в том, что я положил в основание философии не бытие, а свободу. В такой радикальной форме этого, кажется, не делал ни один философ. В свободе скрыта тайна мира. Бог захотел свободы и отсюда произошла трагедия мира. Свобода в начале и свобода в конце. У меня есть основное убеждение, что Бог присутствует лишь в свободе и действует лишь через свободу. Лишь свобода должна быть сакрализована, все же ложные сакрализации, наполняющие историю, должны быть десакрализированы». ${ }^{66}$

Принципиальным в этом вопросе для Бердяева была целостность человека как индивидуального

\footnotetext{
Ареопагит, О божественных именах. О мистическом богословии, Санкт-Петербург 1995, с. 137-167.

64 P. Evdokimov, Prawosławie, Warszawa 1964, c. 227

65 Там же.

66 Н. Бердяев, Самопознание, Москва 1990, с. 52. Философ „свободы” пошел дальше и транспонировал феномен свободы на категорию благодати: «Просветляющая благодать и есть высшая свобода. Бог действует в свободе и через свободу, и вне свободы благодати нет. Традиционное противоположение свободы и благодати в теологической литературе поверхностно и не идет в глубину вопроса. Когда человек совершенно свободен, то он в благодати. Это есть пробуждение божественного элемента в человеке. Если без свободы невозможно принятие благодати, нет для этого органа, то без благодати нет окончательного освобождения человека от необходимости, рабства и фатума. Это все тоже тайна богочеловечности». Н. Бердяев, Истина и откровение, Санкт-Петербург 1996, с. 69.
}

феномена, характеризуя который ученый использовал два понятия - индивидуум и личность. Согласно философу, только личность можно считать действительно свободной и целостной, поскольку она не подчинена ни природе, ни обществу, в отличие от индивидуума, являющегося биологической категорией и подчиненного племени, роду, обществу. В отличие от индивидуума, личность не рождается от родителей, а создается Богом и самосоздается - это и есть идея о человеке.

Идею святости Н. Бердяев постигал, исходя из вышеизложенного феномена человека и категории свободы. Русский мыслитель настаивал на пересмотре концепции святости сообразно современной космической эпохе. Итак, святость Исаака Сирина являлась раннехристианской святостью, достижение которой человеком в современных эпохальных условиях не представлялось возможным. Двухтысячелетнее христианство не устарело, устарело и закостенело понимание действительности и миропорядка, современное понимание святости ученый сравнивает со святостью фарисеев ${ }^{67}$. Современный организм церкви, вступивший в двухтысячелетний возраст, переживает кризис, связанный с критическим периодом мировой истории: «Nie tylko indywidualna doskonałość w walce $\mathrm{z}$ grzechem, ale nawet indywidualna świętość są bezsilne w obliczu kryzysu świata, przed wejściem w inną epokę kosmiczną, w inne stadium objawienia. [...] Niegdyś świętości było więcej niż obecnie. Obecnie świętość wygasa w świecie, ludzkość jakby pozbawiała się daru świętości. [...] Chrześcijańska świętość związana jest z młodością chrześcijaństwa. W chrześcijańskiej świętości zawarta jest wieczna, niegasnąca prawda, ale prawda niepełna, w której nie wszystko zostało wyjawione. [...] Stoimy wobec nowego uświadomienia sobie relacji świętości i genialności, odkupienia i twórczości» $^{68}$.

Таким образом, мы приблизились к Бердяевскому, обновленному пониманию святости. Наряду с традиционным, каноническим интерпретированием святости, философ отстаивал взгляд на существование иной святости - святости в творчестве. Такой святостью для Бердяева была гениальность. Гениальность и святость отнюдь не противоположные и не взаимоисключающиеся явления, а наоборот - взаимодополняющие пути спасения. Разница в этих путях заключается в способе религиозного делания ${ }^{69}$. Если путь к канонической святости лежит через уход от мира и духовное

\footnotetext{
67 Философ выступает с резкой критикой, в частности, св. Феофана Затворника за социальный консерватизм и божественный диктат, изложенный епископом в книге Начертания христианского нравоучения: „Jest to więc cały system podporządkowania i lęku. Nie ma w nim miejsca dla wolności i miłości. Biskup Teofan jest de facto monofizytą: odrzuca człowieka, Bogoczłowieka i Bogoczłowieczeństwo". M. Bierdiajew, Sens twórczości, Kęty 2001, c. 142.

68 Там же, с. 143-144.

69 Для Бердяева гениальность без всяких сомнений является и носит характер религиозного делания.
} 
самосовершенствование, то путь гениальности заключается в отстранении от мира через творчество - гений продолжает жить в миру, являясь для него чужим. Причем как святой в аскезе изнуряет свое тело, так гений жертвует собой в „творческом исступлении”. Философ спрашивает: «в жертве гения, в его творческом исступлении нет ли иной святости перед Богом, иного религиозного делания, равнодостойного канонической святости?» и дает ответ:

«Wierzę głęboko, że geniusz Puszkina, z ludzkiego punktu widzenia jakby gubiący własną duszę, przed Bogiem jest równy świętości Serafina, zbawiającego swoją duszę. Genialność jest inną drogą religijną, równą co do wartości i godności drodze świętego. Twórczość geniusza nie jest dziełem „świeckim”, ale „duchowym”. [...] Twórcza droga geniusza wymaga ofiary nie mniejszej niż ofiara świętości. Na drodze twórczej genialności trzeba wyrzec się „świata”, zwyciężać „świat”. [...] Kto wstąpił na drogę twórczości, drogę genialności, powinien złożyć ofiarę z cichej przystani życiowej, powinien zrezygnować ze swojego szczęścia, $\mathrm{z}$ bezpiecznego urządzenia swojego życia. Do takiej ofiary zdolny jest jedynie ktoś, kto zna ekstazę twórczą, kto w tej ekstazie przekracza granice "świata" ${ }^{70}$.

Утверждение Бердяева о том, что не каждый человек способен быть святым, так же как не каждый может быть гением (для чего необходим соответствующий дар) представляется справедливым лишь во втором случае. Как было показано выше, призвание к святости и ее потенциал заложены в каждом человеке ${ }^{71}$.

Спрашивая о том, что было бы лучше для России - иметь двух великих святых, или иметь святого Серафима и гения Пушкина, философ заключает, что дар гениальности также важен, как и дар святости. Общей задачей и гения и святого является обретение цельной личности в экзистенциальной полноте. В заключение своих рассуждений философ выдвинул постулат о необходимости дополнения культа святости культом гениальности.

Подводя итоги проделанного анализа идеи святости в религиозно-философском понимании, необходимо сделать несколько ключевых выводов. Прежде

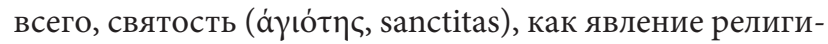
озной жизни, является „фундаментальным концептом христианства"72, однако ее осмысление и дефинирование представляется сложным процессом, заключающимся в рассмотрении разных религиоведческих, феноменологических, философских, социологических и языковедческих составляющих. В рассмотрении данного явления можно выделить четыре смысловых

\footnotetext{
70 M. Bierdiajew, Sens twórczości, Kęty 2001, c. 145-146.

71 Основное утверждение библейской трактовки святости заключается во всеобщем призыве к ней человечества. Ср.: Beтхий 3 aвет, Лев 11:44.

72 С. Климова, Феноменология святости и страстности в русской философии культурь, с. 32.
}

поля: богословское, феноменологическое, философское и социально-этическое.

Православное богословие раскрывает смысл святости на основании Священного Писания, трудов Отцов Церкви, церковных мистиков, и сводит его к причастности человека Богу, достижению каждой конкретной личностью состояния обожения (теозиса), преображения и изменения человеческой природы посредством божественной благодати, благодаря боговочеловечению и боговоплощению Христа.

«Следуя за Христом и согласуя свою волю с природным логосом, человек становится причастником Божества. Конечным моментом этого движения и является обожение (т.е. приобщение к святости - 3.К.)» ${ }^{73}$.

Св. Антоний Великий определил конечную цель христианина как „жизнь в Боге” и назвал ее „верхом совершенства"74. В данной трактовке святости особенное место принадлежит апофатическому богословию и его терминологическому инструментарию ${ }^{75}$.

Феноменологическое рассмотрение святости сосредотачивает свое внимание, прежде всего, на описании внутренних психологических переживаний личности, вступающей в контакт с божеством. Родоначальником данного подхода является Р. Отто, использующий вместо существительного „святость” термин numinosum. Характерным убеждением для данного философа религии была рациональная и иррациональная априорность святости, а ее наивысшим проявлением - Христос. Отто раскрывает не только психические процессы, происходящие в сознании homo religiosus, но также механизмы „притягивания” его к священному.

М. Элиаде продолжил данные исследования и сосредоточился не столько на внутреннем мире, сколько на внешних проявлениях sacrum в чувственно доступной человеку форме - иерофании. Sacrum становится абсолютной онтологически-первичной реальностью, полнотой бытия, причиной всего существующего.

У Джеймса состояние святости человека определяется как наитие свыше и возрождение души, проявляющееся в определенном психо-духовном состоянии. Американский философ выделяет пять главных свойств душевного состояния святого: аскетизм, сила души, чистота души, милосердие.

Русский философ религии Н. Бердяев рассматривает святость в категориях дара свыше и призвания, реализуя которое человек приближается к свободе и приобретает целостность личности. Ученый вводит новое понимание святости - святости в творческой жертве гениальности.

В. Живов, Святость. Краткий словарь агиографических терминов, Москва 1994, http://avorhist.narod.ru/help/ sanct.htm, информация от 27.09.2008 г.

74 Добротолюбие, Свято-Троицкая Сергиева Лавра 1992, Т. 1, с. 138. 75 Апофатическое богословие, в отличие от катафатического, описывает Бога путем отрицаний, т.е. стремиться познать Бога не в том, что Он есть, а в том, что Он не есть. Апофатизм состоит из отрицания всего того, чем Бог не является. См. дет.: В. Лосский, c. 267. 
Л. Дюпре рассматривает sacrum как субъективную категорию и понимает ее на основании оппозиции к profanum. Он также признает существование онтологической реальности, которая стремится поглотить относительную профанную действительность. Благодаря этому, sacrum играет конструктивную консолидирующую роль в обществе, которая однако при полной свободе может привести к узурпации власти и, в конечном счете, к отторжению религии как таковой.

В социально-этическом подходе главное внимание уделяется нравственному и духовному совершенствованию человека и ощутимым результатам его святости, существенным образом влияющим на окружение. Данный подход свойствен Ветхому Завету, а также большинству энциклопедических и толковых словарей, рассматривающих святость как свойство, принадлежащее конкретному лицу - ее носителю. Характерно, что именно старо-библейское понятие святости отож- дествлялось с нравственным совершенством. Святой человек всегда наделен высокой нравственностью, душевной чистотой и совершенством. Семантика корня свят восходит к праславянским корням и имеет глубокую дохристианскую сакральную наполненность.

Таким образом, феномен святости как явление может рассматриваться в нескольких семантических плоскостях: 1) святость как святость, т.е. свойство, исключительно присущее Богу и Его избранникам, достижение которой возможно в процессе обожения; 2) святость как numinosum, т.е. особое религиозное измерение, вызывающее в столкновении с сознанием индивида определенные духовно-психические переживания; 3) святость как sacrum, т.е. иная сфера бытия, онтологическая действительность, первореальность, проявляющая себя в иерофаниях; и, наконец, 4) святость как совершенство, т.е. нравственное качество, достигаемое отдельным человеком в процессе духовного роста.

\section{Bibliografia}

Брауер К., Святость в евангелиях. Возвращение к библейскому представлению о святости в XXI веке, Санкт-Петербург 2009, с. 12.

Буряковский А., Глобализация и философия религии как прикладная дисииплина, [в:] Религия и нравственность в секулярном мире, Санкт-Петербург 2001, с. 79-82.

Бердяев Н., Самопознание, Москва 1990, с. 52

Бердяев Н., Истина и откровение, Санкт-Петербург 1996, c. 69.

Волин Б., Ушаков Д., Толковый словарь русского языка, Москва 1940, Т. 4, с.110

Даль В., Толковый словарь живого великорусского языка, Москва 2001, Т. 4, с. 161.

Словарь современного русского титературного языка, ред. А. Бабкин, Москва-Ленинград 1962, Т. 11, с. 468-472.

Дионисий Ареопагит, О божественных именах. О мистическом богословии, Санкт-Петербург 1995, с. 137-167.

Добротолюбие, Т. 2, Свято-Троицкая Сергиева Лавра 1992, с. 39.

Дьяченко Г., Полный Церковно-славянский словарь, Москва 1998, с. 584; Полный православный богословский энииклопедический словарь, Лондон 1971, Т. 2, с. 2015.

Живов В., Святость. Краткий словарь агиографических терминов, Москва 1994, http://avorhist.nar od.ru/help/sanct. htm, информация от 27.09.2008 г.

Климова С., Феноменология святости и страстности в русской философии культуры, Санкт-Петербург 2004, с. 31.

Лосский В., Очерк мистического богословия Восточной Церкви, [в:] Мистическое богословие, Киев 1991, с. 247-249.

Мень А., Библиологический словарь, Москва 2002, Т. 3, с. 88.

Канонизации святых, Троице Сергиева Лавра 1988, с. 3-4.

Минин П., Главные направления древне-иерковной мистики, [в:] Мистическое богословие, Киев 1991, с. 339.
Ожегов С., Шведова Н., Толковый словарь русского языка, Москва 1999, с. 705.

Слова прп. Симеона Нового Богослова, Москва 2001, с. 487488.

Ссылки на Священное Писание приводятся по: Библия. Книги Священного Писания Ветхого и Нового Завета, Mikkeli 1990.

Творения преподобного Максима Исповедника, Москва 1993, кн. I, http://www.krotov.info/acts/07/2/ isp _ 1_185.html, информация от 10.07.2008 г.

Христианство. Энииклопедический словарь, ред. С. Аверинцев, А. Мешков, Москва 1995, Т. 2, с. 527.

Топоров В., Святость и святые в русской духовной культуре, Т.1, Москва 1995, с.7-9.

Успенский Л., Богословие иконь Православной Церкви, Москва 2007.

Bierdiajew M., Sens twórczości, Kęty 2001, c. 142.

Dupré L., Inny wymiar. Filozofia i religia, Kraków 2003, c. 17.

Eliade M., Sacrum i profanum, Warszawa 1996, c. 6-7.

Eliade M., Traktat o historii religii, Warszawa 2000, c. 395.

Evdokimov P., Prawosławie, Warszawa 1964, c. 227.

James W., Doświadczenia religijne, przeł. J. Hempel, Kraków 2001, c. 209.

Khoury A., Leksykon podstawowych pojęć religijnych, Warszawa 1998, c. 1042.

Otto R., Świętość, Warszawa 1999, c. 5-7.

Pseudo-Dionysius Areopagita, O Imionach Bożych, Lublin 1995; Тот же, Pisma teologiczne, Kraków 2005;

Św. Augustyn, Wyznania, Warszawa 1955, c. 243.

Zdybicka Z., Człowiek i religia, Lublin 2006, c. 238.

Zelek A., Czym jest świętość?, Ząbki 2005, c. 17-18. 